\title{
Assessment of Inbred Lines of Maize for Water Stress Tolerance in Field Conditions
}

\author{
S. Ashwini*, Ashutosh Singh and Pavankumar Jingade \\ Department of Plant Biotechnology, University of Agricultural Science, GKVK, \\ Bangalore 560065, Karnataka, India \\ *Corresponding author
}

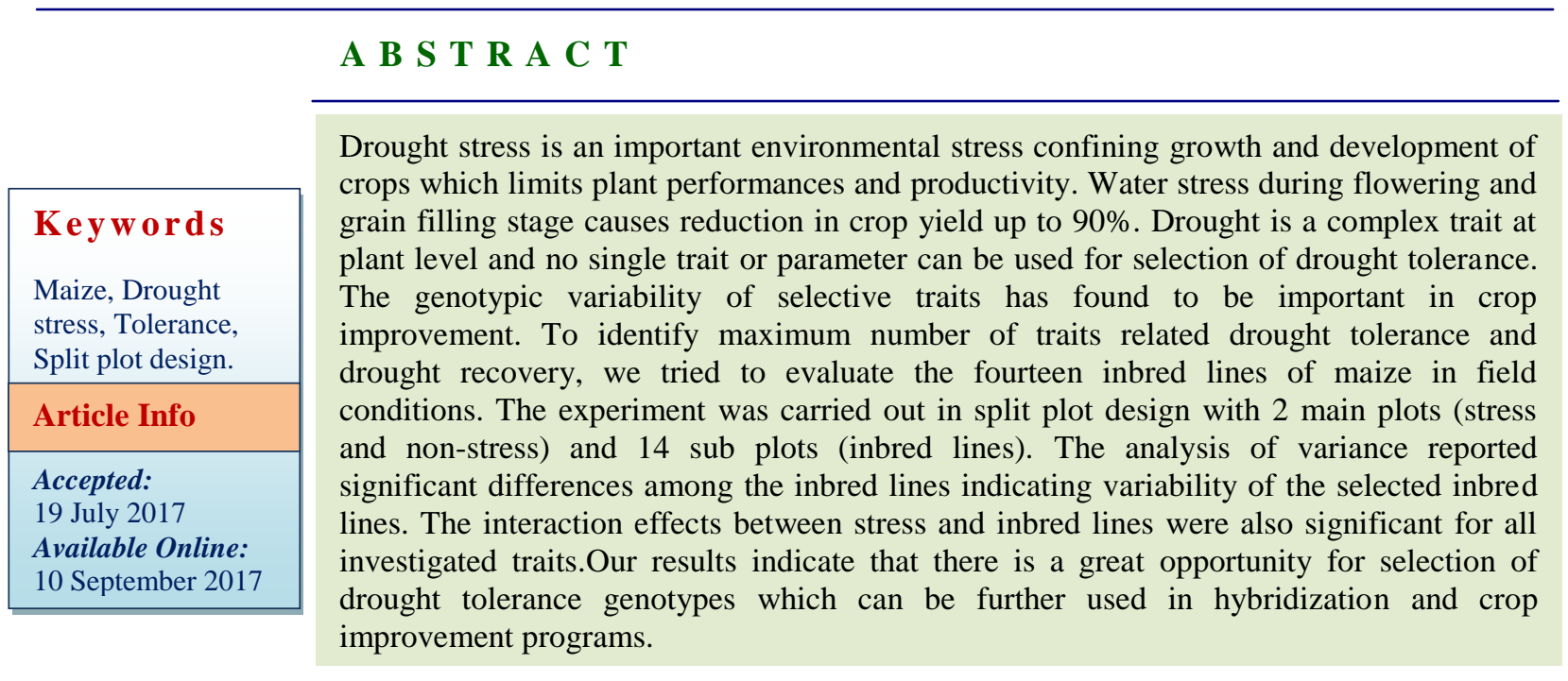

\section{Introduction}

Maize is an important cereal crop grown all over the world. It is known as queen of cereals because it has the highest genetic yield potential among the cereals. It is the only cultivated species with greater economic importance in the tribe Maydeae of the family Poaceae and plays an enormous role in food and nutritional security worldwide. Maize is one of the most versatile emerging crops having wider adaptability under varied agroclimatic conditions (Dowswell et al., 1996). The environmental stresses such as drought, heat, salinity, pollution, heavy metals and pesticides are major limiting factors in crop production (Hernandez et al., 2001; Lawlor and Comic, 2002). Drought stress is a major environmental stress that has negative impacts on plant growth and development which limits plant performances and productivity causing the loss of about $50 \%$ of agricultural yields worldwide (Bray et al., 2000).It inhibits cell growth, cell expansion thereby affecting leaf extension, leaf area, chlorophyll content, growth rate, reproductive development and source- sink relationship (NeSmith and Ritchie, 1992; Hsiao and $\mathrm{Xu}$, 2000; Pandey et al., 2000; Jaleel et al., 2009). Meiosis, anthesis, male and female reproductive stage are all extremely susceptible to drought stress thus leading to a significant yield penalty (Cattivelli et al., 2008; Zinselmeier et al., 1995). 
In maize, the drought affects all growth stages from seedling to grain filling stage. The extent of yield reduction depends not only on the severity of drought occurrence but also on the stage of crop. Drought during germination results in reduction of germination percentage, germination rate, seed vigor, radicle length, plumule length and crop stand (Khayatnezhad, 2010; Khodarahmpour, 2011; Batool et al., 2014). Water stress at vegetative stage causes reduction in relative water content, leaf area development and plant height. Short-duration water deficits during the rapid vegetative growth period leads to 28-32\% loss of final dry matter weight ( $\mathrm{Lu}$ and Neumann, 1998; Cakir, 2004; Chen et al., 2012).Maize is highly susceptible to drought at flowering stage. Reproductive development which determines sink strength, especially over the period of time from about one week before to one week after flowering has found to be highly sensitive to water stress (Claasen and Shaw, 1970; Zinselmeier et al., 1999).

Drought during this crucial stage results in stimulation of protandrous pattern of development and increasing the anthesissilking interval. Maize has short period of flowering and pollen remains viable for only short period of time and each day delay between pollen shed and silk emergence will reduce the rate of sexual fertilization and increase barrenness thereby finally affecting the yield of the plant (Sangoi and Salvador, 1998).Nesmith and Ritchie (1992) also have reported that yield reductions in maize were up to $90 \%$ when drought occurs prior to tassel emergence and during grain filling stage.

Agricultural practices to mitigate drought have their own importance but genetic improvement of plants can fill the gap up to $30 \%$ between theoretical yield and the actual yield under drought conditions (Edmeades et al., 2004). The use of genetics to improve drought tolerance and provide yield stability is an important part of the solution to stabilizing global maize production. But drought tolerance is a very complex trait influenced by a broad range of processes spanning both the time scale and at the plant organization level. Genotypic variability of selective traits for drought tolerance can be utilized in this regard which have been claimed to be important in crop improvement (Maiti et al., 1994; Rosa-Ibarra and Maiti, 1995). The selection of genotypes with wide variability and diversity in respect to drought tolerance becomes crucial.The objective of this study was to evaluate and select maize cultivars for tolerance to drought in field conditions so that they can be used in further crop improvement programs.

\section{Materials and Methods}

The experiment was conducted for during rabi2015 in experimental field of UAS, GKVK campus, Bangalore, India under irrigated and stress conditions. The experimental material comprises of fourteen maize inbred lines viz. BTM1, BTM2, BTM4, BTM5, ВТМ6, ВТМ7, ВТМ10, ВТМ13, BTM14, BTM15, ВTM 18, BTM 19, DT3 and MAI105. The experiment was laid out in a split plot design with two main plot (Stress and Non-stress) treatments and fourteen genotypes as sub-plot treatments in two replications. The inbred lines were sown with a spacing of $30 \mathrm{~cm}$ between plants and $60 \mathrm{~cm}$ between the rows and as one row per genotype. The recommended Phosphorus and Potash (each at the rate of $125 \mathrm{~kg} \mathrm{ha}^{-1}$ ) was applied at the time of sowing while Nitrogen (at the rate of $250 \mathrm{~kg} \mathrm{ha}^{-1}$ ) was applied in a two split dose. All the necessary agronomic practices were timely followed to ensure good plant stand. All the plots were irrigated immediately after sowing and irrigation was given to all plots at an interval of 5 days. After 45 days from sowing and before flowering initiation, the irrigation was 
withheld for the stressed plot treatments up to 20 days whereas the non-stressed (control) plot was irrigated at regularly till physiological maturity. The weather data for the crop period has been recorded and presented in table 1 .

\section{Morphological observations}

In each treatment and replication the observations of randomly selected five plants were considered. The growth parameters like plant height $(\mathrm{cm})$, days to tassel initiation, days to $50 \%$ anthesis and days to silking were measured. The cobs were harvested at physiological maturity and the yield parameters recorded were cob length $(\mathrm{cm})$, cob diameter $(\mathrm{cm})$, number of rows per cob, number of seeds per cob, test weight $(\mathrm{g})$ and grain yield per plant (g). The mean of all the five observations were used for analysis.

\section{Statistical analysis}

Split plot statistical analysis was carried out to analyze the variance of the traits for which the observations were recorded to ensure the existence of significant differences between treatments, within treatments and their interaction (Jayaraman, 1999).

\section{Results and Discussion}

In the present study, drought was induced through the most critical stage of life cycle for water requirement so as to identify effect of moisture stress on inbred lines in natural field conditions. The effect of drought stress on the growth and yield parameters were not found to be significant. However, there were significant differences for all traits viz. days to tassel initiation, days to silking, days to anthesis, cob length, cob diameter, number of rows per cob, number of seeds per cob, test weight and grain yield per plant among inbred lines. The analysis of variance also showed that the interaction effects between stress and inbred lines were significant for all investigated traits (Table 2).

The inbred lines showed the significant variation for plant height and number of seeds whereas the variation was not significant for the other traits. This is due to the frequent rainfall encountered during the stress period, which disrupted the stress treatment. Significant variation in plant height may be due to the stress treatment encountered by plants before the occurrence of rainfall. Olawuyi et al., (2015) has reported the positive correlation between plant height and drought stress supporting our observations. The rainfall which occurred during the reproductive stage may have caused the plants to adapt to drought stress and resulted in recovery of yield and other yield parameters (Chen et al., 2016).

The comparisons of treatment means revealed that maximum plant height was recorded in BTM7 $(132 \mathrm{~cm})$ and minimum in BTM14 $(82.50 \mathrm{~cm})$ (Table 3). The mean days to silking and anthesis ranged from 57 days to 71 days indicating variability in time required for reproductive development. Inbred line BTM13 required lowest days for reproductive phase development signifying drought escaping strategy in plants (Basu et al., 2016). The highest test weight and yield per plant was recorded in BTM6 (28.31g) and BTM10 (115.1g) while both traits recorded lowest in BTM14 (12.88g and 35.90g) respectively. Correspondingly, all the other parameters recorded showed variability among the inbred lines. The results indicated the vast diversity and variability among the inbred lines which can be further utilized in hybridization programs. Similarly, Maiti et al., (1996) had reported large variations in resistance to drought and saline stress in maize cultivars. Grzesiak (2001) also observed considerable genotypic variability among various maize genotypes for different traits which could be used in selection for drought tolerance. 
Table.1 Weather Data for cropping period sown during rabi 2015 at University of Agricultural Sciences, GKVK, Bangalore

\begin{tabular}{|c|c|c|c|c|c|}
\hline Month & $\begin{array}{c}\text { Total rainfall } \\
(\mathbf{m m})\end{array}$ & $\begin{array}{c}\text { Mean relative } \\
\text { humidity (per cent) }\end{array}$ & $\begin{array}{c}\text { Mean maximum air } \\
\text { temperature }\left(\mathbf{~}^{\mathbf{0}} \mathbf{C}\right)\end{array}$ & $\begin{array}{c}\text { Mean minimum air } \\
\text { temperature }\left({ }^{\mathbf{}} \mathbf{C}\right)\end{array}$ & $\begin{array}{c}\text { Mean daily } \\
\text { Sunshine (hours) }\end{array}$ \\
\hline September-15 & 254.6 & 91 & 28.7 & 19.2 & 5.5 \\
\hline October-15 & 80.8 & 89 & 29.3 & 19.1 & 6.6 \\
\hline November-15 & 180.4 & 94 & 25.3 & 17.9 & 3.3 \\
\hline December-15 & 4.2 & 91 & 27.6 & 19.9 & 6.5 \\
\hline
\end{tabular}

Table.2 ANOVA for growth and yield traits of different maize inbred lines in irrigated and stressed condition

\begin{tabular}{|c|c|c|c|c|}
\hline Source & Replication & Main plot (C) & Sub plot (G) & $\mathbf{G} \times \mathbf{C}$ \\
\hline Plant height (cm) & $433.71 * *$ & $3932.98 *$ & $990 * *$ & $315.89 * *$ \\
\hline Tassel Initiation & 21.86 & 11.15 & $69.86 * *$ & $22.35 * *$ \\
\hline Days to Silking & 19.44 & 50.16 & $54.32 * *$ & $16.85 * *$ \\
\hline Days to Anthesis & 20.63 & 16.05 & $65.26 * *$ & $17.22 * *$ \\
\hline Cob length (cm) & 0.24 & 2.41 & $10.12 * *$ & $2.02 * *$ \\
\hline Cob diameter $(\mathrm{cm})$ & 0.054 & 0.05 & $0.47 * *$ & $0.06 * *$ \\
\hline No. of rows per cob & 2.55 & 5.76 & $23.28 * *$ & $14.16^{* *}$ \\
\hline No. of seeds per cob & $419.10 *$ & $12447.10^{*}$ & $13781.13^{* *}$ & $1208.67 * *$ \\
\hline Test weight (g) & 3.22 & 31.04 & $66.72 * *$ & $4.3 * *$ \\
\hline Grain yield per plant $(\mathrm{g})$ & 31.29 & 38.23 & $3.95 * *$ & $7.56 * *$ \\
\hline
\end{tabular}

$* *$ Significant at $1 \%$ probability level $*$ Significant at $5 \%$ probability level

Table.3 Mean values of growth and yield parameters of different maize inbred lines

\begin{tabular}{|l|l|l|l|l|l|l|l|l|l|c|}
\hline & \multicolumn{1}{|c|}{ PH } & \multicolumn{1}{|c|}{ DT } & \multicolumn{1}{c|}{ DS } & \multicolumn{1}{|c|}{ DA } & \multicolumn{1}{|c|}{ COL } & \multicolumn{1}{c|}{ COD } & \multicolumn{1}{c|}{ NOR } & NOS & TW & YP \\
\hline BTM 1 & 84.81 & 60.00 & 69.25 & 64.00 & 9.56 & 3.72 & 24.56 & 456.77 & 12.53 & 57.05 \\
\hline BTM 2 & 122.98 & 63.25 & 66.75 & 67.75 & 10.56 & 3.78 & 19.90 & 268.13 & 18.44 & 53.01 \\
\hline BTM 4 & 113.13 & 68.50 & 72.00 & 71.25 & 11.55 & 3.91 & 23.27 & 293.56 & 21.44 & 63.48 \\
\hline BTM 5 & 114.23 & 67.25 & 71.50 & 71.00 & 13.66 & 3.99 & 27.02 & 415.67 & 20.17 & 85.62 \\
\hline BTM 6 & 103.54 & 66.25 & 67.75 & 68.50 & 13.94 & 3.63 & 21.75 & 281.94 & 28.31 & 89.87 \\
\hline BTM 7 & 132.00 & 63.25 & 64.50 & 65.75 & 13.75 & 3.74 & 28.81 & 433.21 & 19.88 & 86.36 \\
\hline BTM 10 & 120.56 & 62.00 & 69.00 & 67.75 & 12.38 & 3.84 & 24.17 & 352.58 & 24.33 & 115.1 \\
\hline BTM 13 & 92.38 & 53.50 & 57.75 & 57.50 & 9.94 & 3.00 & 21.19 & 287.90 & 19.31 & 73.86 \\
\hline BTM14 & 82.50 & 63.75 & 69.50 & 68.00 & 11.75 & 3.41 & 22.25 & 277.63 & 12.88 & 35.90 \\
\hline BTM 15 & 86.90 & 68.50 & 68.50 & 71.25 & 12.11 & 3.47 & 23.58 & 313.81 & 18.88 & 58.80 \\
\hline BTM 18 & 101.88 & 59.50 & 64.50 & 63.50 & 11.91 & 3.59 & 23.13 & 347.75 & 20.36 & 70.66 \\
\hline BTM 19 & 97.13 & 66.25 & 71.00 & 71.75 & 13.28 & 3.66 & 24.38 & 295.44 & 20.92 & 61.88 \\
\hline DT 3 & 101.73 & 65.75 & 67.75 & 70.25 & 8.97 & 3.35 & 18.17 & 272.50 & 17.35 & 54.91 \\
\hline MAI 105 & 124.00 & 60.00 & 65.50 & 63.75 & 12.97 & 4.53 & 25.33 & 407.92 & 21.26 & 86.39 \\
\hline Mean & 107.67 & 63.41 & 67.51 & 67.28 & 11.62 & 3.68 & 23.36 & 339.62 & 19.78 & 65.02 \\
\hline CD @ 5\% & 10.76 & 3.11 & 2.64 & 3.47 & 1.57 & 0.41 & 4.20 & 71.41 & 2.75 & 23.45 \\
\hline
\end{tabular}

PH: Plant height; DT: Days to tassel initiation; DS: Days to Silking; DA: Days to Anthesis; COL: Cob length; COD: Cob diameter; NOR: Number of rows per cob; NOS: Number of seeds per cob; TW: Test weight; YP: Grain yield per plant

*Significant at $5 \%$ probability level 
Table.4 Mean values and percent reduction of growth and yield parameters in irrigated $(\mathrm{N})$ and stressed condition(S)

\begin{tabular}{|c|c|c|c|c|c|c|c|c|c|c|c|c|c|c|c|c|c|c|c|c|}
\hline & \multicolumn{2}{|c|}{$\mathbf{P H}$} & \multicolumn{2}{|c|}{ DT } & \multicolumn{2}{|c|}{ DS } & \multicolumn{2}{|c|}{$\mathbf{D A}$} & \multicolumn{2}{|c|}{ COL } & \multicolumn{2}{|c|}{ COD } & \multicolumn{2}{|c|}{ NOR } & \multicolumn{2}{|c|}{ NOS } & \multicolumn{2}{|c|}{ TW } & \multicolumn{2}{|c|}{$\mathbf{Y P}$} \\
\hline & $\mathbf{N}$ & $\mathbf{S}$ & $\mathbf{N}$ & $\mathbf{S}$ & $\mathbf{N}$ & $\mathbf{S}$ & $\mathbf{N}$ & $\mathbf{S}$ & $\mathbf{N}$ & $\mathbf{S}$ & $\mathbf{N}$ & $\mathbf{S}$ & $\mathbf{N}$ & $\mathbf{S}$ & $\mathbf{N}$ & $\mathbf{S}$ & $\mathbf{N}$ & $\mathbf{S}$ & $\mathbf{N}$ & $\mathbf{S}$ \\
\hline BTM 1 & 84.33 & 85.29 & 60.50 & 59.50 & 69.50 & 69.00 & 65.00 & 63.00 & 9.63 & 9.50 & 3.69 & 3.75 & 24.83 & 24.29 & 455.58 & 457.96 & 13.44 & 11.63 & 0.61 & 0.53 \\
\hline BTM 2 & 128.63 & 117.33 & 63.50 & 63.00 & 67.00 & 66.50 & 68.00 & 67.50 & 10.88 & 10.25 & 3.69 & 3.88 & 21.46 & 18.33 & 277.50 & 258.75 & 18.88 & 18.00 & 0.52 & 0.54 \\
\hline BTM 4 & 106.88 & 119.38 & 73.00 & 64.00 & 76.00 & 68.00 & 75.50 & 67.00 & 10.94 & 12.17 & 3.81 & 4.00 & 22.58 & 23.96 & \begin{tabular}{|l|}
260.33 \\
\end{tabular} & 326.79 & 18.75 & 24.13 & 0.49 & 0.79 \\
\hline BTM 5 & 106.33 & 122.13 & 73.00 & 61.50 & 77.50 & 65.50 & 75.50 & 66.50 & 13.00 & 14.31 & 3.92 & 4.06 & 25.67 & 28.38 & 384.75 & 446.58 & 17.09 & 23.25 & 0.67 & 1.04 \\
\hline BTM 6 & 133.71 & 73.38 & 63.00 & 69.50 & 66.00 & 69.50 & 66.00 & 71.00 & 14.75 & 13.13 & 3.63 & 3.63 & 23.50 & 20.00 & 306.00 & 257.88 & 29.38 & 27.25 & 1.11 & 0.70 \\
\hline BTM 7 & 147.38 & 116.63 & 62.50 & 64.00 & 65.00 & 64.00 & 65.50 & 66.00 & 14.50 & 13.00 & 3.67 & 3.81 & 30.50 & 27.13 & \begin{tabular}{|l|l}
449.17 \\
\end{tabular} & 417.25 & 19.50 & 20.25 & 0.88 & 0.85 \\
\hline BTM 10 & 149.13 & 92.00 & 61.00 & 63.00 & 68.50 & 69.50 & 66.50 & 69.00 & 12.25 & 12.50 & 3.75 & 3.94 & 24.67 & 23.67 & 372.54 & 332.63 & 26.50 & 22.17 & 1.27 & 1.03 \\
\hline BTM 13 & 98.50 & 86.25 & 54.00 & 53.00 & 59.50 & 56.00 & 59.50 & 55.50 & 9.13 & 10.75 & 2.69 & 3.31 & 20.50 & 21.88 & 236.67 & 339.13 & 20.50 & 18.13 & 0.49 & 0.97 \\
\hline BTM14 & 84.33 & 80.67 & 65.00 & 62.50 & 71.50 & 67.50 & 69.50 & 66.50 & 10.69 & 12.81 & 3.44 & 3.38 & 24.25 & 20.25 & 310.13 & 245.13 & 13.75 & 12.00 & 0.43 & 0.30 \\
\hline BTM 15 & 88.13 & 85.67 & 68.50 & 68.50 & 68.00 & 69.00 & 71.50 & 71.00 & 11.56 & 12.67 & 3.63 & 3.31 & 23.08 & 24.08 & \begin{tabular}{|l|}
329.63 \\
\end{tabular} & 298.00 & 18.38 & 19.38 & 0.60 & 0.57 \\
\hline BTM 18 & 106.63 & 97.13 & 59.50 & 59.50 & 65.50 & 63.50 & 63.00 & 64.00 & 12.69 & 11.13 & 3.63 & 3.56 & 25.25 & 21.00 & 386.13 & 309.38 & 19.50 & 21.21 & 0.76 & 0.66 \\
\hline BTM 19 & 104.88 & 89.38 & 64.00 & 68.50 & 70.00 & 72.00 & 70.00 & 73.50 & 12.81 & 13.75 & 3.88 & 3.44 & 18.29 & 30.46 & 252.25 & 338.63 & 20.96 & 20.88 & 0.54 & 0.71 \\
\hline DT 3 & 111.38 & 92.08 & 65.00 & 66.50 & 67.50 & 68.00 & 69.00 & 71.50 & 9.35 & 8.58 & 3.46 & 3.25 & 21.58 & 14.75 & 322.83 & 222.17 & 17.17 & 17.54 & 0.61 & 0.46 \\
\hline MAI 105 & 138.00 & 110.00 & 61.50 & 58.50 & 67.00 & 64.00 & 65.00 & 62.50 & 13.56 & 12.38 & 4.63 & 4.44 & 25.50 & 25.17 & 403.50 & 412.33 & 22.03 & 20.50 & 0.88 & 0.84 \\
\hline Mean & 116.05 & 99.29 & 63.85 & 62.96 & 68.46 & 66.57 & 67.82 & 66.75 & 11.83 & 11.42 & 3.71 & 3.65 & 23.69 & 23.04 & 354.53 & 324.71 & 20.52 & 19.03 & 66.34 & 63.71 \\
\hline
\end{tabular}

PH: Plant height; DT: Days to tassel initiation; DS: Days to Silking; DA: Days to Anthesis; COL: Cob length; COD: Cob diameter; NOR: Number of rows per cob; NOS: Number of seeds per cob; TW: Test weight; YP: Grain yield per plant 
All the growth and yield parameters viz. plant height, cob length, cob diameter, number of rows per cob, number of seeds per cob, test weight and grain yield per plant recorded lower values in stressed condition compared to nonstressed condition (Table 4). Non-stressed condition had a mean of 116.05 plant height, $11.86 \mathrm{~cm}$ cob length, $3.71 \mathrm{~cm}$ cob diameter, 23.69 number of rows per cob, 354.53 number of seeds per cob, $20.52 \mathrm{~g}$ test weight, $66.34 \mathrm{~g}$ grain yield per plant while the stressed condition exhibited a mean of 99.29 plant height, $11.42 \mathrm{~cm}$ cob length, $3.65 \mathrm{~cm}$ cob diameter, 23.04 number of rows per cob, 324.71 number of seeds per cob, $19.03 \mathrm{~g}$ test weight, $63.71 \mathrm{~g}$ grain yield per plant (Table 4). In accordance with our results, Ziyomo et al., (2013) also had demonstrated that under drought conditions, the mean grain yields for the drought tolerant maize hybrids ( $9.66 \mathrm{mg} \mathrm{ha}^{-1}$ ) was significantly more than drought-susceptible maize hybrids (5.46 mg ha ${ }^{-1}$ ) involving 10 maize hybrids.

In earlier studies, it has been reported that grain yield reduced by $25 \%$ to $73.5 \%$ when drought was induced during post anthesis stage (Pandey et al., 2000; Olaoye et al., 2009).Our results recorded only $3.96 \%$ reduction in total grain yield indicating drought adaptation after rainfall.The results of this study indicate that maize inbred lines have large potential to display variations to drought tolerance. Under the drought condition, the discovery of variability among maize inbred lines in growth and yield parameters provide an ample opportunity for the selection of genotypes for tolerance to drought. As it has been reported that genetic variation is essential prerequisite for any crop improvement programs, sampling more variables at more time points along with final grain yields will provide us with a better understanding of drought-adaptive mechanisms. The genetic variation in the present study for drought tolerance reflected genotypic differences which require further work to rigorously test the genetic basis of these genotypic differences. The divergent responses to drought stress help the breeders to explore in greater detail that influence drought tolerance.

\section{References}

Basu, S., V. Ramegowda, A. Kumar and Pereira, A.2016.Plant adaptation to drought stress.F1000 Res. 1554: 1-10.

Batool, N., N. Ilyas, T. Noor, M. Saeed, R. Mazhar, F. Bibi and Shahzad, A. 2014. Evaluation of drought stress effects on germination and seedling growth of Zea mays L. Int. J. Biosci., 5(4): 203-209.

Bray, E. A., J. Bailey-Serres and Weretilnyk, E. 2000.Responses to abiotic stresses. Biochem. Mol. Bio. Plant (Rockv). 1: 11581249.

Cakir, R., 2004.Effect of water stress at different development stages on vegetative and reproductive growth of corn.Field Crops Res. 89: 1-16.

Cattivelli, L., F. Rizza, F. Badeck, E. Mazzucotelli, E. M Mastrangelo, E. Francia, C. Mare, A. Tondelli and Stanca, M. 2008. Drought tolerance improvement in crop plants: An integrated view from breeding to genomics. Field Crops Res. 105: 1-14.

Chen, D., S. Wang, B. Cao, D. Cao, G. Leng, H. Li, L. Yin, L. Shan and Deng, X. 2016. Genotypic Variation in Growth and Physiological Response to Drought Stress and Re-Watering Reveals the Critical Role of Recovery in Drought Adaptation in Maize Seedlings. Front. Plant Sci. 6: 1241.

Chen, J., W. Xu, J. Velten, Z. Xin, and Stout, J. 2012. Characterization of maize inbred lines for drought and heat tolerance. J. soil water conserve. 67(5): 354-364.

Claasen, M. M., and Shaw, R. H.1970. Water deficit effects on grain. II. Grain components. Agron. J. 62: 652-655.

Dowswell, L. R., R. L. Paliwal and Canrell, R. P. 1996.Maize in the third world. West View Press. pp. 1-37.

Edmeades, G. D., M. Banziger, J. R. Schussler and Campos, H. 2003. Improving abiotic stress tolerance in maize: a random or planned process, in proceedings of the Aruel, R. Hllauer international symposium on Plant Breeding. Mexico, Lowa State 
University Press.

Hernandez, J. A., M. A. Ferrer, A. Jimenez, A. R. Barceló and Sevilla, F. 2001. Antioxidant system and $\mathrm{O} 2 / \mathrm{H} 2 \mathrm{O} 2$ production in the apoplast of Pisum sativum L. leaves: its relation with $\mathrm{NaCl}$-induced necrotic lesions in minor veins. Plant Physiol. 127: 817 831

Hsiao, T. C., and Xu, L. 2000. Sensitivity of growth of roots versus leaves to water stress: biophysical analysis and relation to water transport. J. Exp. Bot. 51(350): 15951616.

Jaleel, C. A., P. Manivannan, A. Wahid, M. Farooq, H. J. Al-Juburi, R. Somasundaram and Panneerselvam, R. 2009. Drought stress in plants: a review on morphological characteristics and pigments composition. Int. J. Agric. Biol. 11: 100-105.

Jayaraman, K., 1999.A Statistical manual for Forestry Research. Food and Agriculture Organization of the United Nations Regional office for Asia and the Pacific Bangkok publication. pp. 91-114.

Khayatnezhad, M., R. Gholamin, S. Jamaati-ESomarin and Zabihie- Mahmoodabad, R. 2010.Effects of PEG Stress on Corn cultivars (Zea mays L.) at germination stage. World Appl. Sci. J. 11(5): 504-506.

Khodarahmpour, Z., 2011. Effect of drought stress induced by polyethylene glycol on germination indices in corn (Zea mays L.) hybrids. Afr. J. Biotech. 10(79): 1822218227.

Lawlor, D.W., and Cornic, G. 2002. Photosynthetic carbon assimilation and associated metabolism in relation to water deficits in higher plants. Plant Cell Environ. 25: 275-294.

Lu, Z., and Neumann, P. M. 1998. Water-stressed maize, barley and rice seedlings show species diversity in mechanisms of leaf growth inhibition. J. Exp. Bot. 49(329): 1945-1952.
Maiti, R. K., L. E. D. Amayai, S. I. Cardona, A. M. Dimasi, M. D. L. Rosa-Ibarra and Castill, H. D. L. 1996.Genotypic Variability in Maize Cultivars (Zea mays L.) for Resistance to Drought and Salinity at the Seedling Stage.J. Plant Physiol. 148: 741744.

Maiti, R. K., M. D. L. Rosa-Ibarra and Sandoval, N. D. 1994. Genotypic variability in glossy sorghum lines for resistance to drought, salinity and temperature stress at the seedling stage. J. Plant Physiol. 143: 241244.

Nesmith, D. S., and Ritchie, J. T. 1992. Effects of soil water-deficits during tassel emergence on development and yield component of maize (Zea mays). Field Crops Res. 28(3): 251-256.

Olawuyi, O. J., O. B. Bello, C. V. Ntube, and Akanmu, A. O. 2015.Progress from selection of some maize cultivars response to drought in the derived Savanna of Nigeria.Agrivita.37(1): 8-17.

Pandey, R. K., J. W. Maranville and Admou, A. 2000. Deficit irrigation and nitrogen effects on maize in a Sahelian environment: I. Grain yield and yield components. Agric. Water Manag.46 (1): 1-13.

Rosa-Ibarra, D. L. M., and Maiti, R. K. 1995.Biochemical mechanism in glossy sorghum lines for resistance to salinity stress. J. Plant Physiol. 146(4): 515-519.

Sangoi, L., and Salvador, R. J. 1998. Maize susceptibility to drought at flowering: A new approach to overcome the problem. Ciencia Rural.28 (4): 699- 708.

Zinselmeier, C., B. Jeong and Boyer, J. S. 1999. Starch and the control of kernel number in maize at low water potentials. Plant Physiol. 121: 25-36.

Zinselmeier, C., M. J. Lauer and Boyer, J. S. 1995. Reversing drought induced losses in grain yield: Sucrose maintains embryo growth in Maize. Crop Sci., 35: 1390-1400.

\section{How to cite this article:}

Ashwini S., Ashutosh Singh and Pavankumar Jingade. 2017. Assessment of Inbred Lines of Maize for Water Stress Tolerance in Field Conditions. Int.J.Curr.Microbiol.App.Sci. 6(9): 1451-1457. doi: https://doi.org/10.20546/ijcmas.2017.609.176 